\title{
The usefulness of ground-penetrating radar images for the research of a large sand-bed braided river: case study from the Vistula River (central Poland)
}

\author{
Anna Lejzerowicz ${ }^{1,2}$, Sebastian Kowalczyk ${ }^{2}$, Anna Wysocka ${ }^{2}$ \\ ${ }^{1}$ Faculty of Civil Engineering, Warsaw University of Technology, Al. Armii Ludowej 16, 00-637 Warsaw, Poland, \\ e-mail: a.lejzerowicz@il.pw.edu.pl \\ ${ }^{2}$ Faculty of Geology University of Warsaw, ul. Żwirki i Wigury 93, 02-089 Warsaw, Poland
}

\begin{abstract}
Ground-penetrating radar (GPR) surveys and sedimentological outcrop analyses were combined in order to determine the reflection patterns and internal architecture of terrace deposits of the Vistula River at Kępa Zawadowska in the southern part of Warsaw (central Poland). The sedimentary analyses concerned the granulometric composition and lithofacies analysis. The 34 GPR profiles, which were obtained in two outcrops, using a Malå RAMAC/GPR system with $500-\mathrm{MHz}$ and $250-\mathrm{MHz}$ shielded antennas, were up to $100 \mathrm{~m}$ long. The most characteristic ground-penetrating radar profiles are presented; they show a high-resolution data set of radar facies. The GPR data suggest the presence of three geophysically different units, namely with high-angle inclined reflections (radar facies 1), with discontinuous undulating or trough-shaped reflections (radar facies 2), and with low-angle reflections (radar facies 3). The internal structure of the fluvial deposits was obtained by integration of the GPR and sedimentological data, which combination provides a more accurate visualisation of sedimentary units than do reconstructions that are based only on standard lithologic point data.
\end{abstract}

Keywords: sedimentary architecture, sand-bed braided river, lithofacies, ground-penetrating radar, radar facies, Vistula River

\section{Introduction}

Ground-penetrating radar (GPR) is a non-invasive geophysical technique widely used for determining shallow geological structures. GPR surveys provide a near-continuous record of sedimentary structures reaching to below the water table, but the interpretation of GPR profiles requires sedimentary data from exposures (Słowik, 2012). The most effective form of ground-truth control is to trench parts of the profile immediately after data collection, if possible (Woodward et al., 2003; Olszak \& Karczewski, 2008).
GPR is commonly used for the investigation of alluvial deposits (e.g. Leclerc \& Hickin, 1997; Vandenberghe \& Van Overmeeren, 1999; Skelly et al., 2003; Woodward et al., 2003; Lunt et al., 2004; Sambrook Smith et al., 2006; Hickin et al., 2009; Rice et al., 2009; Ashworth et al., 2011). Vandenberghe \& Van Overmeeren (1999) showed that the deposits of meandering, braided and transitional river types produce characteristic radar facies from which the specific river pattern can be inferred. The same conclusion was reached by Olszak \& Karczewski (2008), who studied terraces of the Kamienica River in the Polish Outer Carpathians. 
The study by Skelly et al. (2003) of the shallow sand-bed braided Niobrabra River resulted in a set of radar facies representing architectural elements of the braid bar complexes, large and small bedforms, and channels. Woodward et al. (2003) described the key steps required to process and interpret GPR reflections in the sandy fluvial environment of the South Saskatchewan River. Studies conducted by Lunt et al. (2004) allowed to develop a quantitative three-dimensional depositional model of gravelly braided river deposits based on, among others, GPR profiles. Sambrook Smith et al. (2006) used ground-penetrating radar to describe and quantify the deposits of unit bars and compound bars within the sandbed braided South Saskatchewan River. Their study suggests that more GPR studies in other braided-river environments are required to determine whether a single generic facies model can be applied to all braided rivers. Another investigation of the South Saskatchewan River using GPR surveys and coring was conducted by Ashworth et al. (2011), who described the channel evolution and the accumulation of compound bars. Their study showed that in well sorted sandy braided-river deposits it is impossible to distinguish between channel-fill facies and compound-bar facies. In Poland, only few geologists focused their research on GPR (e.g. Haczewski \& Kukulak, 2004; Lamparski, 2004; Olszak \& Karczewski, 2008; Słowik 2011, 2012). Studies by Lamparski (2004) concerned various sedimentary environments (e.g. aeolian, fluvioglacial, fluvial) and showed that application of GPR is very useful in studies of Quaternary sediments. Słowik (2011, 2012) used ground-penetrating radar in the lowland valley of the Odra River to investigate changes in depth range and resolution of GPR surveys under different hydrological conditions and GPR parameter settings; this research showed a high influence of the water content on the depth range and resolution of measurements.

\subsection{Objective}

The main objective of the present study was to verify the usefulness of GPR imaging for sed- imentological studies of sand-bed braided-river deposits in central Poland. GPR surveys and sedimentological field studies were carried out for the purpose at Kępa Zawadowska, south of Warsaw (Fig. 1A, B) in order to characterise the sedimentary architecture and lithofacies of the Vistula River deposits. Such investigations were aimed to characterise in detail the subsurface bedforms of the Vistula River. This study, which was the first GPR study of its kind of a large lowland river in Poland, was aimed at determining the usefulness of GPR imaging for such an analysis.

\section{Study area}

The Vistula River is the longest river in Poland with a length of $1,047 \mathrm{~km}$. The river is divided into three sections (Starkel, 2011): an upper section (from its sources to the city of Sandomierz), a middle one (from Sandomierz to the mouth of the Narew River and the Bug River) and a lower one (from the mouth of the Narew River to the Vistula delta at the Baltic coast). Each river section is characterised by a different channel pattern and a different type of sediment transport, which significantly affects the type and internal architecture of the deposits.

The study area is located in the middle course of the Vistula River valley (Fig. 1A, B), where it is a sand-bed braided river (Babiński, 1992; Falkowski, 2006). This type of river is characterised by a predominance of channel deposition over erosion and contains mid-channel bars (longitudinal, transverse, linguoid and/or compound). In this section, the Vistula River is a quasi-natural fluvial system, i.e. only slightly modified by man.

The middle course of the Vistula River is characterised by a rain/snow regime, resulting in high discharge during early spring and in a low discharge during autumn. The resulting annual fluctuations of the water level are about $4-5 \mathrm{~m}$ to a maximum of about $7 \mathrm{~m}$ (Fal et al., 1997). The average discharge of the Vistula River in the Warsaw area during the years 1951-1990 was $573 \mathrm{~m}^{3} / \mathrm{s}$. From November to April the average discharge was $614 \mathrm{~m}^{3} / \mathrm{s}$ and from May to October it was $533 \mathrm{~m}^{3} / \mathrm{s}$. 
Fig. 1. Study site.

A: Location of the study area on the background of the Hypsometrical Map of Poland (www.mapaswiata.pl; adopted); B: Satellite image with the study sites (www. maps.google.com; adapted); C: Scheme of the GPR profiles at study site 1 (500-MHz antenna, 2011) a: profiles running perpendicular to the Vistula; in violet: excavation site and profiles (I, II) for sedimentological research; D: Scheme of the GPR profiles at study site 2 (250-MHz antenna, 2012; lowest water level of the Vistula River for 300 years. Profiles 1-10 are $100 \mathrm{~m}$ long; profiles 1a-10a: $45 \mathrm{~m}$; profiles 11a, 12a, 13a: $55 \mathrm{~m}$; distance between the profiles $1 \mathrm{~m}$; a: profiles running perpendicular to the Vistula.
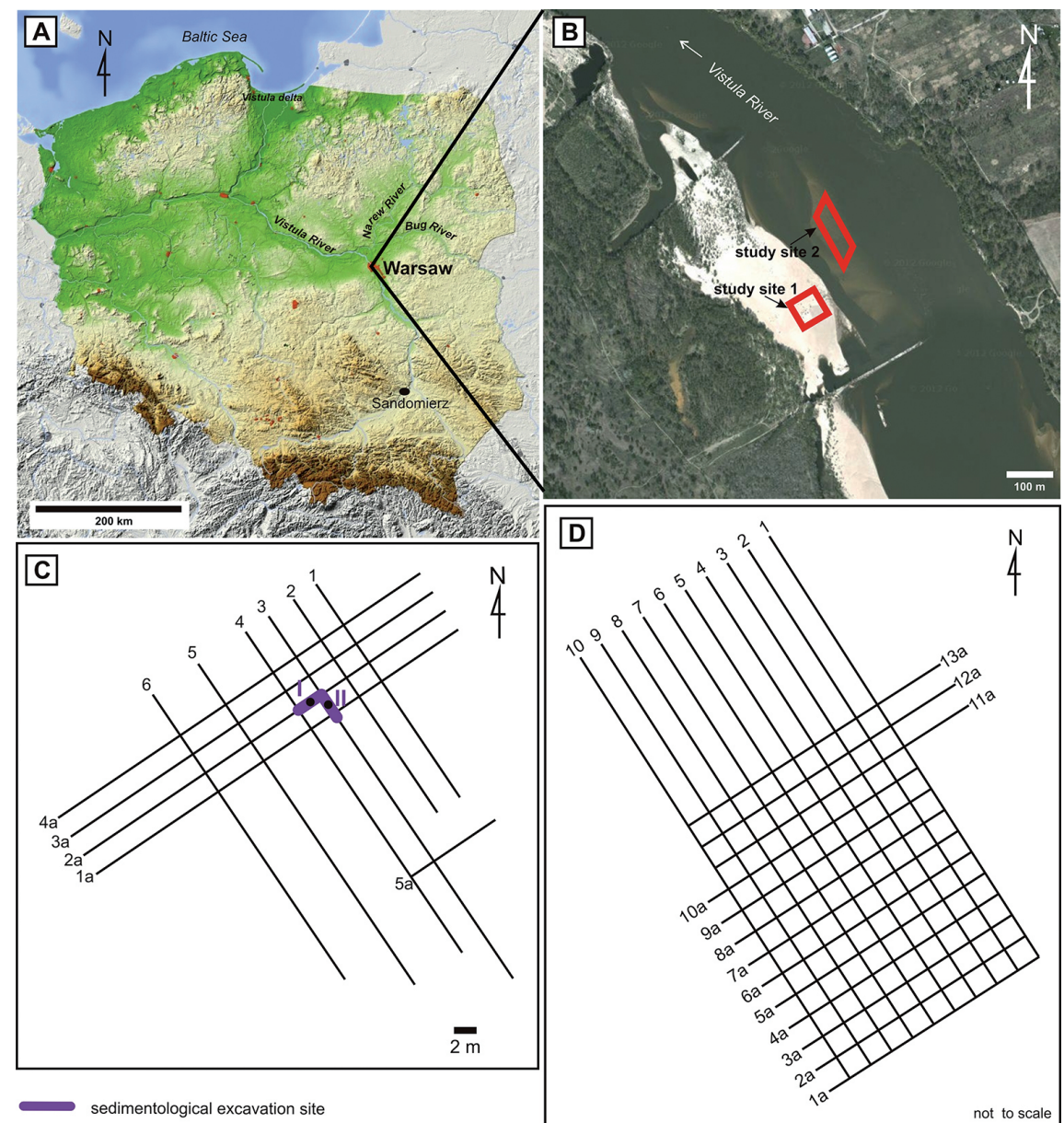
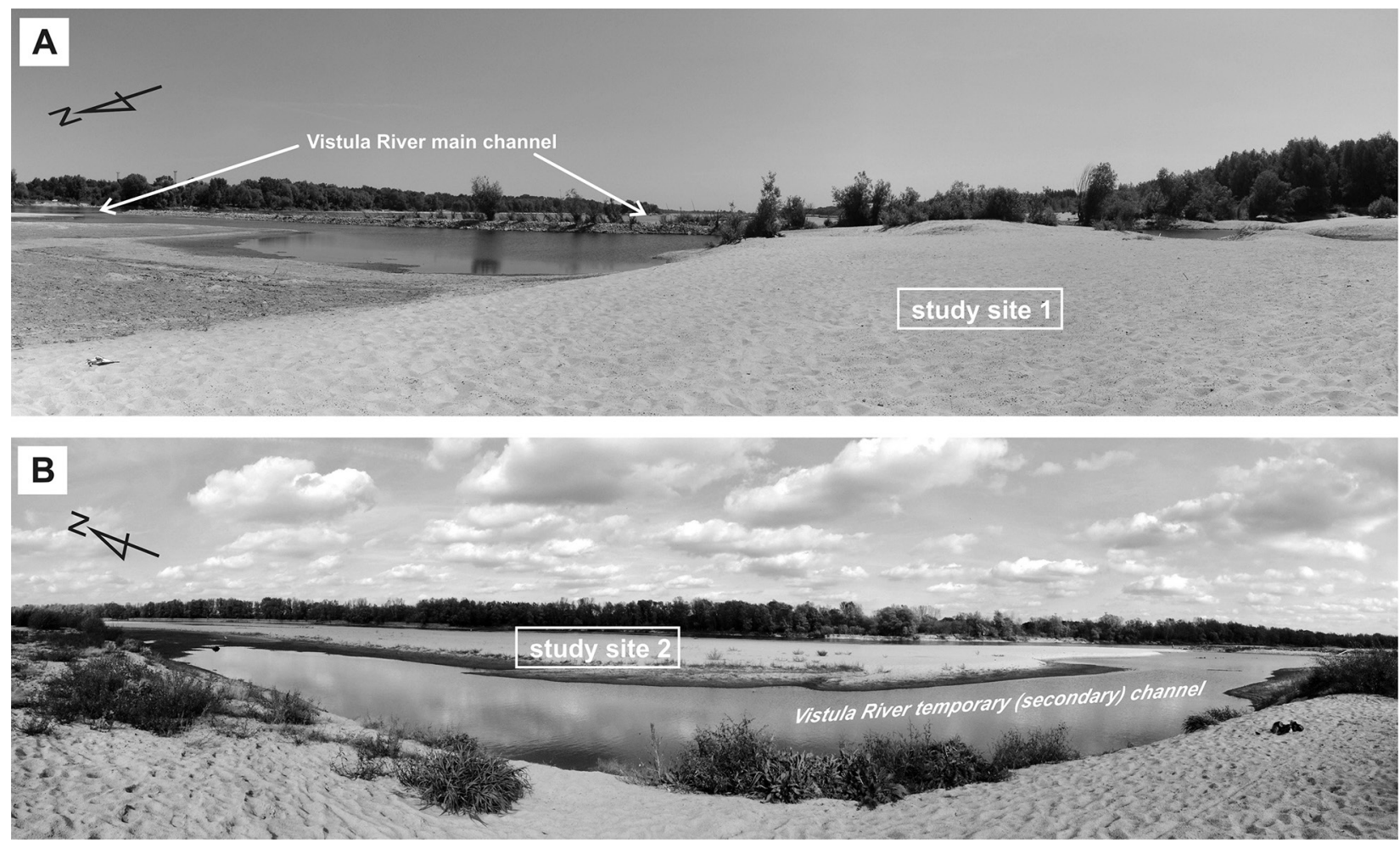

Fig. 2. Impression of study sites 1 (A) and 2 (B). 
Two study sites (1 and 2; for location, see Fig. 1B) were selected to analyse the internal architecture of the river's sandy deposits. Site 1 is located on a partly overgrown sandy bank. It has a differentiated morphology (Fig. 2A) and it is flooded only during high water. In June 2011, the outcrop was dug to document the lithology of the deposits. GPR and sedimentary studies were carried out at this site in October 2011.

Site 2 is located on a sandbar adjacent to the main course of the river, which seasonally is cut-off from the floodplain by a temporary channel (Fig. 2B). Even during medium water stages, it is completely submerged. GPR and sedimentary studies were carried out at this site in October 2012 during unusually low water.

\section{Methods}

Both sites were studied by (1) using ground-penetrating radar and (2) carrying out sedimentological analyses.

\subsection{Ground-penetrating radar}

The GPR method is a high-resolution, mobile and non-invasive geophysical method. It is a very-high-frequency electromagnetic technique used to produce a high-resolution images from the subsurface. GPR is used in order to characterise the subsurface architecture and to detect certain objects in the ground. The GPR signal is reflected back to the antenna by materials with contrasting dielectric and conductivity properties (Daniels, 2004; Neal, 2004; Jol, 2009). For the purpose a pulse of an electromagnetic wave of known frequency is sent. An electromagnetic wave then penetrates into the medium where it is partially reflected and refracted as well as damped (resulting from a change in electrical parameter). In recorded images (radargrammes), the electromagnetic waves are analysed that were reflected from the boundaries between deposits characterised by different values of their dielectric constant $\left(\varepsilon_{\mathrm{r}}\right)$. The 'quality' (reflection strength, ampli- tude) of the image thus obtained depends on the contrast of the electrical properties between the two media.

The penetration depth of GPR depends on the frequency of the transmitting antenna and on the properties of the medium. For the same geological medium, a lower wave frequency enables investigation to a greater depth range, but at the cost of a lower resolution of the measurements (Daniels, 2004; Lamparski, 2004; Jol, 2009; Karczewski et al., 2011). The depth range depends strongly on the dielectric constant of the deposits. Beds with a high dielectric constant can be distinguished on the basis of the attenuation of the electromagnetic wave. Due to the fact that water has the highest dielectric constant $\left(\varepsilon_{\mathrm{r}}=81\right)$, the water table adversely affects signal propagation by reducing the vertical range of GPR prospecting.

Minimum values of the dielectric constant occur in dry sedimentary rocks with a high porosity (Karczewski et al., 2011). The dielectric constant, which is determined by the electrical properties of the solid particles and the content of pore water, increases with increasing moisture content. Therefore, the highest dielectric constant for mineral soils exists in loose, water-saturated sand.

Data were collected using the RAMAC/ GPR system produced by MalåGeoscience. A penetration depth up to $4 \mathrm{~m}$ with a $500-\mathrm{MHz}$ and $250-\mathrm{MHz}$ shielded antenna allowed the unravelling of the internal architecture of the

Table 1. GPR parameter settings used during this study.

\begin{tabular}{lcc} 
& $\begin{array}{c}500- \\
\text { MHz } \\
\text { antenna } \\
\mathbf{2 0 1 1}\end{array}$ & $\begin{array}{c}\mathbf{2 5 0 -} \\
\mathbf{M H z} \\
\text { antenna } \\
\mathbf{2 0 1 2}\end{array}$ \\
\hline traces & $205-894$ & $\begin{array}{c}1010(\mathrm{~S}-\mathrm{N} \\
\text { profiles) } \\
460(\mathrm{E}-\mathrm{W} \\
\text { profiles) }\end{array}$ \\
trace interval [m] & 0.0494 & 0.0989 \\
number of measurements & 740 & 354 \\
number of stacks & 4 & 4 \\
time window [ns] & 76 & 122 \\
antennae spacing (separation) [m] & 0.18 & 0.36 \\
penetration depth [m] & $\approx 3$ & $\approx 4$ \\
\hline
\end{tabular}


fluvial deposits. The GPR measurements were carried out using two different antennas (Table 1) to test the usefulness of antennas of varying frequency for investigation of alluvial covers of sand-bed braided-river terraces in the Polish lowland. Antennas with different frequencies were also used to show the internal architecture in different resolutions: a $500-\mathrm{MHz}$ antenna has a higher resolution but a less depth range (up to $5 \mathrm{~m}$ during optimal conditions), whereas the $250-\mathrm{MHz}$ antenna has greater depth range (up to $8 \mathrm{~m}$ during optimal conditions) but a lower resolution. The GPR profiles were processed using ReflexW version 6.0 and included the following six processes.

(1) Dewow was used to remove any very-low-frequency components. A dewow filter works independently for each route (it is a 1-D filter) by calculating the average value of each route and subtracting the moving average of the midpoint (median value of the window).

(2) Static correction was carried out to correct zero time (the first arrival). The correct setting of the time of the first arrival of a wave is necessary for the proper location of the reflections on the depth scale.

(3) AGC-gain (Automatic Gain Control) is a way to strengthen the weak signals. This strengthening is the normalisation of the amplitude to a constant level in the window of predetermined length. Thus, the filter amplifies inversely proportionally to the signal strength. Therefore all parts of the signal, including noise, are amplified and relative information about the amplitude is not preserved.

(4) Background removal is obtained through a filter that eliminates time-line noise of the entire profile (2-D filter), thereby exposing the real, drowned out signal. Using this filter is one of the most common procedures, particularly for GPR data.

(5) Bandpass frequency: a transmitting bandpass filter was applied to cut the unwanted noise at low and high frequencies.

(6) The average xy-filter filter calculates the average over a selectable $x y$-area for each time step. This filter improves the correlation of useful reflections, smoothes horizontal data and improves the image readability (and makes features more visible).
Application of the above-mentioned processing steps was intended to improve the 'quality' of the raw data, which would facilitate the interpretation of the radargrams. Topographic correction was not applied because the study area was flat and the height differences ranged up to some centimetres only.

At the end of the processing, a time-depth related conversion was made based on the matching of the hyperbola.

The 34 GPR profiles (up to $100 \mathrm{~m}$ long) were collected inform the two test sites (for location, see Fig. 1) in two successive years. In 2011 (site 1) a $500-\mathrm{MHz}$ shielded antenna was used and in 2012 (site 2) a 250-MHz shielded antenna was used to investigate the internal architecture of the sandy braided-river deposits. In 2011, just after data collecting by GPR, a shallow (up to $1 \mathrm{~m}$ ) trench was dug (sedimentological site; for location, see Fig. 1C). Direct comparison of the GPR data with the outcrop verified the correctness of the GPR data (Fig. 1C).

\subsection{Sedimentological analyses}

The sedimentological characteristics were studied in two intersecting outcrops. The sediment architecture was recorded using a combination of digital photographs, sketches and sedimentary logs. A lithofacies code, based on Miall (1977, 1985), Eyles et al. (1983), Zieliński $(1995,1998)$ and Zieliński \& Pisarska-Jamroży (2012) was used for the description of the facies and structures (Table 2). Sedimentary logs made on the basis of the outcrops dug in October 2011 were compared with photos of out-

Table 2. Codes of the textural and structural elements of the various lithofacies; modified after Miall (1977, 1985), Eyles et al. (1983), Zieliński $(1995,1998)$ and Zieliński \& Pisarska-Jamroży (2012).

\begin{tabular}{|c|c|c|c|}
\hline Code & Texture & Code & Structure \\
\hline G & gravel & $\mathrm{m}$ & massive \\
\hline$S$ & sand & $\mathrm{h}$ & horizontal lamination \\
\hline F & silt & $\mathrm{p}$ & $\begin{array}{l}\text { planar cross-stratifica- } \\
\text { tion }\end{array}$ \\
\hline \multirow[t]{2}{*}{$\mathrm{C}$} & organic material & $\mathrm{r}$ & $\begin{array}{l}\text { ripple cross-stratifica- } \\
\text { tion }\end{array}$ \\
\hline & & 1 & $\begin{array}{l}\text { low-angle cross-strati- } \\
\text { fication }\end{array}$ \\
\hline
\end{tabular}


crops dug in June 2011 (Fig. 3 A, B) at site 1. The aim was to find differences in the geometry of this sandy bar that had developed during a short time span.

Two sedimentary profiles were analysed for their granulometry and sedimentary structures. Twelve sediment samples were collected for grain-size analyses by sieving (for results, see Table 3). On the basis of laboratory analyses, the mean grain size $\left(M_{z}\right)$ - expressed in $\varphi$-values, standard deviation $\left(\sigma_{1}\right)$ and skewness $\left(\mathrm{Sk}_{1}\right)$ were calculated using the Folk \& Ward (1957) method. For their interpretation, the comments of Mycielska-Dowigałło (1995, 2007) and Racinowski et al. (2001) were taken into account. The lithofacies were recognised and distinguished according to their average grain size, sorting and stratification, and then compared with ground-penetrating radar images.

\section{Sedimentology of the Vistula River sandbars}

As mentioned above, the sedimentological investigation involved lithofacies analysis and analysis of the various granulometric parameters.

\subsection{Lithofacies analysis}

Lithofacies were analysed in two profiles (I and II) from study site 1. Their locations are shown in Figure 1.

\subsubsection{Profile I}

This profile is located in the outcrop perpendicular to the Vistula River channel at site 1. The profile (Fig. 3A) consists of sand with ripple cross-stratification (Sr), planar cross-stratified sand $(S p)$ and sand with a massive structure $(\mathrm{Sm})$ in the uppermost part (for the lithology, see Table 2). Also a thin layer of organic deposits $(C)$ - clay rich in organic matter - is present, which can be connected with sedimentation of the finest particles from stagnant water after a flood event. The dip direction of the laminae of the planar cross-stratified sands is toward the main channel of the river.

\subsubsection{Profile II}

This profile is located in the outcrop parallel to the river channel (for location, see Fig. 1C) at site 1. The profile (Fig. 3B) is composed of sands with ripple $(\mathrm{Sr})$ and horizontal/low-angle (Sh/ Sl) cross-stratification (for lithology, see Table 2). A thin layer of massive gravelly sand (SGm) is present between the two other sand lithofacies. Thin layers of finer massive fines $(\mathrm{Fm})$ and organic clay $(C)$ are also present. Lithofacies

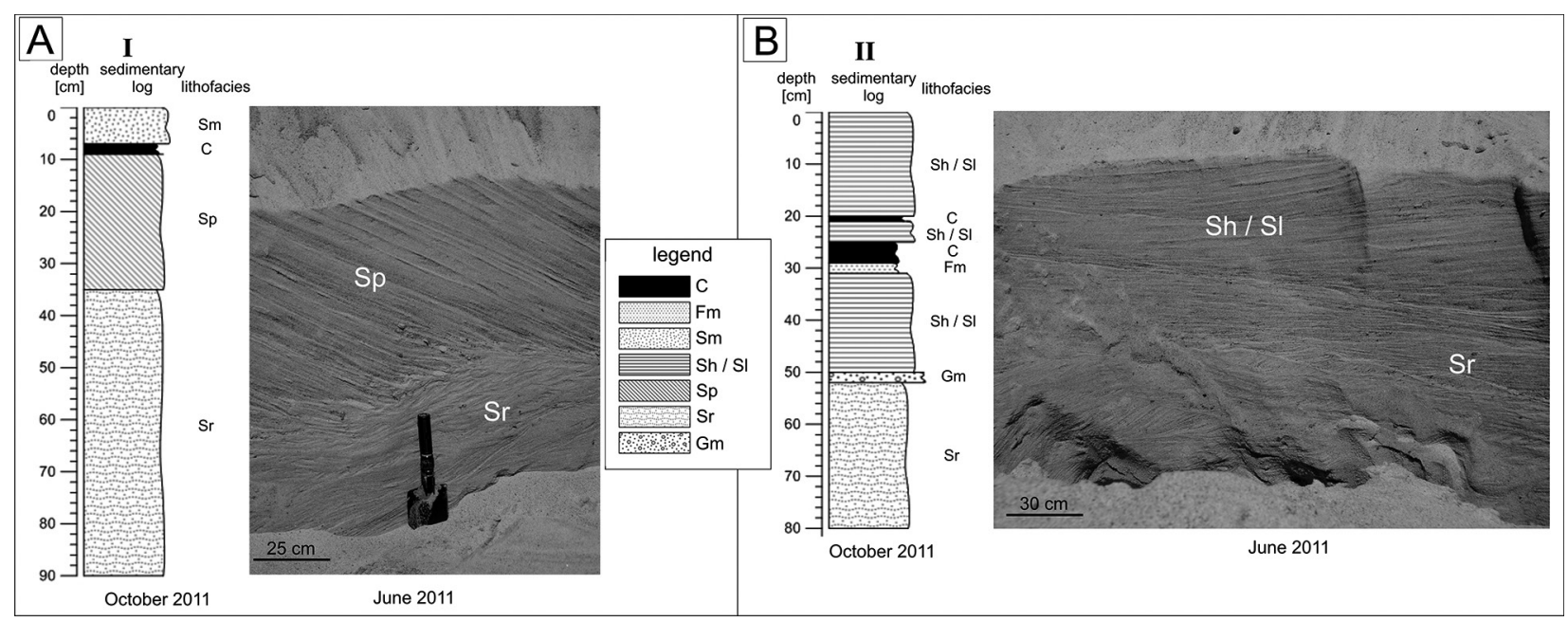

Fig. 3. Sedimentary logs from study site 1 made on the basis of outcrops dug in October 2011 compared with outcrops dug in June 2011.

A: Outcrop perpendicular to the Vistula River (purple line I in Fig. 1C); B: Outcrop parallel to the Vistula River (purple line II in Fig. 1C). 
Sh/Sl gradually passes into horizontally stratified sand in the upper part of the profile.

\subsubsection{Similarities and differences of both profiles}

The facies succession in both profiles indicates sedimentation in a flood-plain environment that was periodically submerged during high water. Comparison of the two sedimentary profiles shows only slight changes in the internal architecture of site 1.

The following four major lithofacies assemblages are commonly present in the sandy bars.

(1) Stratified sands $(S h / S l, S p, S r)$. These are common in the study area. They may be interbedded with finer deposits $(F m, C)$ or with the coarser ones $(\mathrm{SGm})$. The lithofacies are well sorted, with a dominant medium-grained sand fraction (40-62\% by weight) with coarse and fine-grained sands (10-46\% by weight). The sands are either horizontally laminated/low-angle cross-stratified $(S h / S l)$, planar cross-stratified $(S p)$ or ripple cross-stratified $(S r)$. Lithofacies $S h / S l$ was deposited after bedload transport at higher current velocities. Lithofacies $S p$ was formed under lower flow-regime conditions. Lithofacies Sr represents deposition of finer sediment transported as bedload.

(2) Massive fines $(\mathrm{Fm})$ and organic deposits (C). These two lithofacies comprise clay- and silt-sized deposits. The lithofacies occur locally as centimetre-thick deposits within the sandy succession. They reflect waning phases of floods and the deposition of finest material from suspension and weak currents.

(3) Massive sands $(\mathrm{Sm})$. These are dominated by the medium-sand fraction $(>50 \%$ by weight). They are well sorted sediments with only small admixtures of finer and coarser sands, most commonly in the upper parts of the profiles. The massive structure may be primary or secondary, resulting from wind, rain or human activity on top of a sandbar.

(4) Massive gravelly sands (SGm). The gravel lithofacies are characterised by the presence of about $10 \%$ pebbles by weight (see Table 3 ), with a matrix of sand with only a small admixture of finer fractions (less than 1\%). The granules and pebbles are well rounded. This lithofacies is interpreted as deposited from highly concentrated bedload transport by strong currents during a flooding.

Table 3. Results of sieve analyses of 12 sediment samples from site 1 ( 5 samples) and site 2 (7 samples) in October 2011. The grain-size content is expressed in \% by weight. For lithofacies codes, see Table 2.

\begin{tabular}{|c|c|c|c|c|c|c|c|c|c|}
\hline \multirow{3}{*}{$\begin{array}{l}\text { Sam- } \\
\text { ple } \\
\text { num- } \\
\text { ber }\end{array}$} & \multirow{3}{*}{$\begin{array}{l}\text { Litho- } \\
\text { facies }\end{array}$} & \multicolumn{7}{|c|}{ Granulometry } & \multirow{3}{*}{ Type of dominant sediment } \\
\hline & & \multicolumn{2}{|c|}{ Gravel fraction } & \multicolumn{5}{|c|}{ Sand \& silt fractions } & \\
\hline & & $\begin{array}{l}>4 \\
\mathrm{~mm}\end{array}$ & $\begin{array}{c}4.0-2.0 \\
\mathrm{~mm}\end{array}$ & $\begin{array}{c}2.0-1.0 \\
\mathrm{~mm}\end{array}$ & $\begin{array}{c}1.0-0.5 \\
\mathrm{~mm}\end{array}$ & $\begin{array}{l}0.5- \\
0.25 \\
\mathrm{~mm}\end{array}$ & $\begin{array}{c}0.25- \\
0.1 \mathrm{~mm}\end{array}$ & $\begin{array}{l}<0.1 \\
\mathrm{~mm}\end{array}$ & \\
\hline I 1 & Sp & 0.6 & 0.5 & 1.8 & 17.4 & 40.6 & 38.5 & 0.5 & medium and fine sand \\
\hline I 2 & $\mathrm{Sp}$ & 0.2 & 0.1 & 1.7 & 31.8 & 49.5 & 16.7 & 0.0 & medium and coarse sand \\
\hline I 3 & $\mathrm{Sp}$ & 1.0 & 0.6 & 2.3 & 26.9 & 45.9 & 23.3 & 0.0 & medium, coarse and fine sand \\
\hline I 4 & $\mathrm{Sr}$ & 0.4 & 0.3 & 1.2 & 19.8 & 53.6 & 24.7 & 0.1 & medium sand \\
\hline I 5 & $\mathrm{Sr}$ & 0.1 & 0.2 & 1.3 & 17.7 & 51.9 & 28.6 & 0.2 & medium sand \\
\hline II 1 & $\mathrm{Sp}$ & 0.2 & 0.3 & 1.9 & 33.0 & 44.5 & 20.1 & 0.0 & medium and coarse sand \\
\hline II 2 & $\mathrm{Sr}$ & 0.2 & 0.2 & 1.1 & 20.3 & 56.9 & 21.2 & 0.1 & medium sand \\
\hline II 3 & $\mathrm{Sr}$ & 0.7 & 0.2 & 1.4 & 13.0 & 62.4 & 22.1 & 0.2 & medium sand \\
\hline II 4 & $\mathrm{Sh} / \mathrm{Sl}$ & 1.1 & 0.5 & 0.8 & 17.8 & 49.0 & 30.1 & 0.7 & medium and fine sand \\
\hline II 5 & $\mathrm{Gm}$ & 4.8 & 4.9 & 8.3 & 26.6 & 36.9 & 18.2 & 0.4 & medium and coarse sand \\
\hline II 6 & $\mathrm{Sr}$ & 0.0 & 0.4 & 1.2 & 10.4 & 41.3 & 46.5 & 0.1 & fine and medium sand \\
\hline II 7 & $\mathrm{Sm}+\mathrm{Fh}$ & 0.0 & 0.0 & 1.2 & 21.9 & 57.4 & 18.4 & 1.2 & medium sand \\
\hline average & & 0.8 & 0.7 & 2.0 & 21.4 & 49.2 & 25.7 & 0.3 & medium, fine and coarse sand \\
\hline
\end{tabular}




\subsection{Grain-size parameters}

Table 4 shows the grain-size parameters of the deposits: the mean grain size $\left(\mathrm{M}_{\mathrm{z}}\right)$ in $\varphi$-values, the standard deviation $\left(\sigma_{1}\right)$ and the skewness $\left(\mathrm{Sk}_{1}\right)$.

\subsubsection{Mean grain size $\left(M_{z}\right)$}

The range and mean grain sizes are 0.98 $1.83 \varphi$ and $1.46 \varphi$, respectively. The average mean grain-size indicates a predominance of medium sand, but in individual samples this parameter may vary (see Table 3 ). The range of the mean grain sizes indicates that the sediments were transported in saltation (cf. Racinowski et al., 2001).

\subsubsection{Standard deviation $\left(\sigma_{1}\right)$}

The values of $\sigma_{1}$ range from 0.62 to $1.25 \varphi$ (average $0.74 \varphi$ ), indicating moderate sorting and moderate changes of the current energy. Only in one sample (II 5: see Table 4), the poor sorting suggests that the sediment was deposited in the channel zone with a relatively strong current.

\subsubsection{Skewness $\left(\mathrm{Sk}_{1}\right)$}

The skewness values indicate mostly nearly symmetrical skewed sediments (9 samples: $S r$, $S p, S h / S l$ and $S m$ lithofacies). rare negatively skewed (2 samples: $S p$ and $S r$ lithofacies) and a single very negatively skewed sample (SGm

Table 4. Grain-size parameters of the samples from the Vistula River at Kępa Zawadowska.

\begin{tabular}{crccc}
\hline \multirow{2}{*}{$\begin{array}{c}\text { Sample } \\
\text { number }\end{array}$} & \multicolumn{4}{c}{ Grain-size parameters } \\
\cline { 2 - 5 } & median & Mz & $\mathbf{\sigma}_{1}$ & Sk $_{1}$ \\
\hline I 1 & 1.74 & 1.61 & 0.77 & -0.23 \\
\hline I 2 & 1.32 & 1.28 & 0.72 & -0.07 \\
\hline I 3 & 1.40 & 1.35 & 0.76 & -0.09 \\
I 4 & 1.51 & 1.49 & 0.69 & -0.09 \\
\hline I 5 & 1.60 & 1.58 & 0.68 & -0.09 \\
II 1 & 1.32 & 1.29 & 0.73 & -0.05 \\
II 2 & 1.47 & 1.47 & 0.66 & -0.05 \\
\hline II 3 & 1.51 & 1.58 & 0.62 & 0.05 \\
II 4 & 1.56 & 1.58 & 0.65 & -0.01 \\
\hline II 5 & 1.15 & 0.98 & 1.25 & -0.31 \\
\hline II 6 & 1.89 & 1.83 & 0.68 & -0.19 \\
\hline II 7 & 1.43 & 1.42 & 0.67 & -0.03 \\
\hline I
\end{tabular}

I 1-I 5: samples collected from profile I; II 1-II 7: samples collected from profile II (for location, see Fig. 1C). lithofacies). Overall, 11 samples are characterised by less or more admixtures of coarse grains. In our opinion, this suggests that the sediments underwent reworking in the Vistula channel.

\section{Ground-penetrating radar profiles}

Ground-penetrating radar profiles were made from both study sites (Figs 4 and 5), with interpretation of their internal structure. The GPR profiles from site 1 (Fig. 4) show higher-angle reflections than those from site 2 (Fig. 5). This is due to wash-out of sediments during high-water stages. The reflections dip toward the main channel of the Vistula River and show the current direction during waning stages. The water table was quite deep (about $1.8 \mathrm{~m}$ ) in 2012, but it was not reached at all in 2011 (Fig. 1C).

The GPR profiles from site 2 (Fig. 5) have lower-angle reflections. Erosional surfaces are visible but channel structures are not present. In profile 6 (Fig. 5B), a clear set of layered sediments is visible. Their dip direction indicates that the sediments were deposited by northward directed currents. Because site 2 is close to the Vistula River (Fig. 1D), the sediments were subjected to frequent changes of current energy, resulting in deposition of alternating layers of different grain sizes. The water table is very shallow and it is visible in all GPR profiles.

In GPR profiles running perpendicular to the river, the sediments dip towards the main channel at both sites (Figs 4A, 5A). In the GPR profiles parallel to the river (Figs $4 \mathrm{~B}, 5 \mathrm{~B}$ ), the sediments dip according to the current direction in the main river channel. In all profiles erosional surfaces are visible which indicate the successive stages of erosion (strong currents during high water stages) followed by deposition (decelerating currents during waning flood stages).

The GPR data suggest the presence of three geophysically different units (Figs 4, 5). Characterisation of these units is based on relationships between the reflections, their shapes and the geometry of the bounding surfaces (cf. 


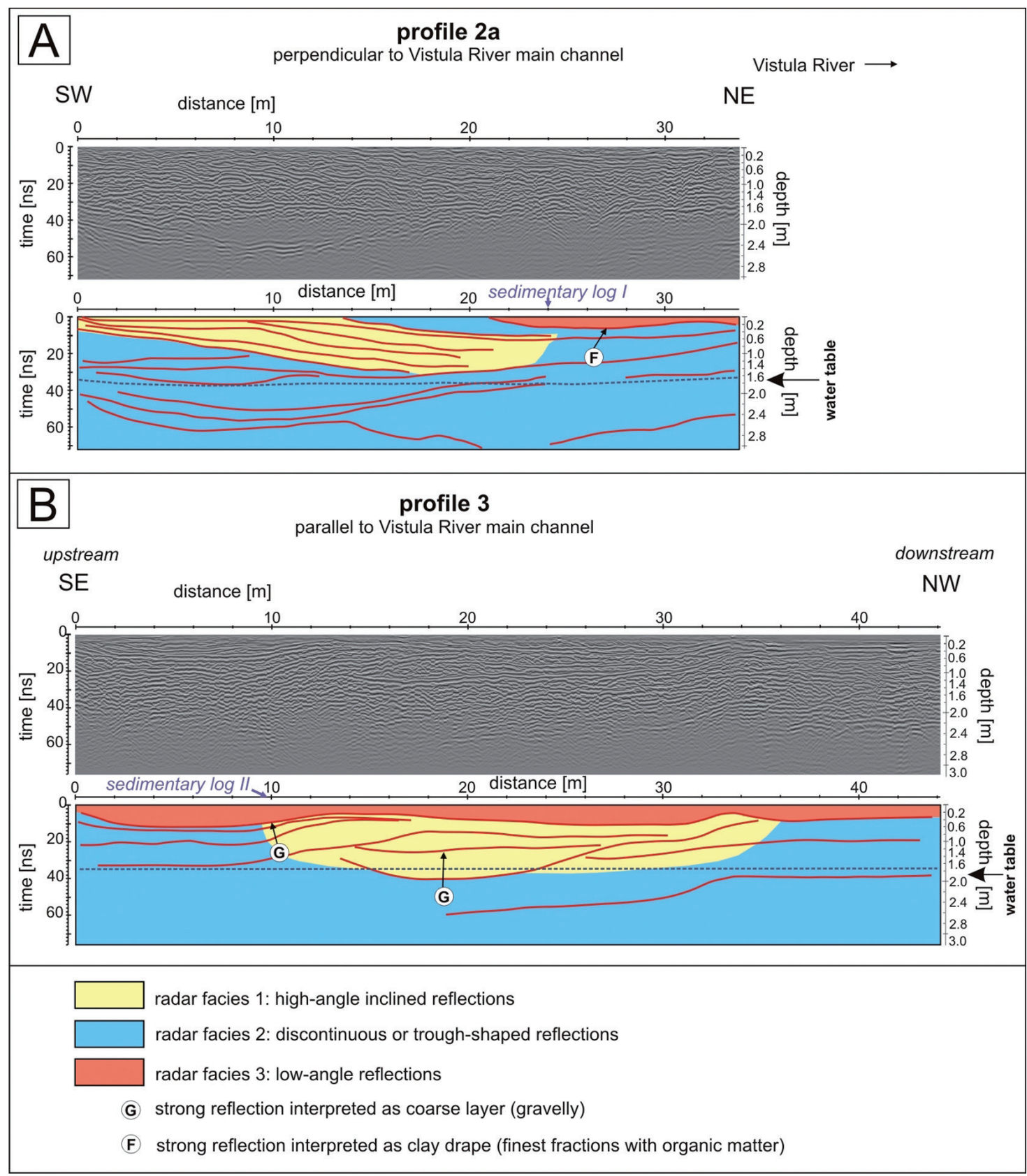

Fig. 4. GPR profiles obtained using 500-MHz antennas (site 1, 2011; for location see Fig. 1) with corresponding interpretations. The GPR trace shows examples of three principal radar facies that are characteristic of the sandy braided-river deposits of the Vistula River; on both profiles the locations of the sedimentary logs are indicated.

A: Profile 2a running perpendicular to the main channel of the Vistula River; B: Profile 3 running parallel to the main channel of the Vistula River.

Neal, 2004; Jol, 2009) and on the classification proposed by Sambrook Smith et al. (2006) and Ashworth et al. (2011). The following three radar facies were thus recognized (examples are shown in Figs 4 and 5).

\subsection{Radar facies 1: high-angle inclined reflections}

Facies 1 is characterised by dipping parallel reflections. It consists of reflections with inclinations from $6^{\circ}$. They are interpreted as largescale inclined strata formed by migration of bar margins (Sambrook Smith et al., 2006). 

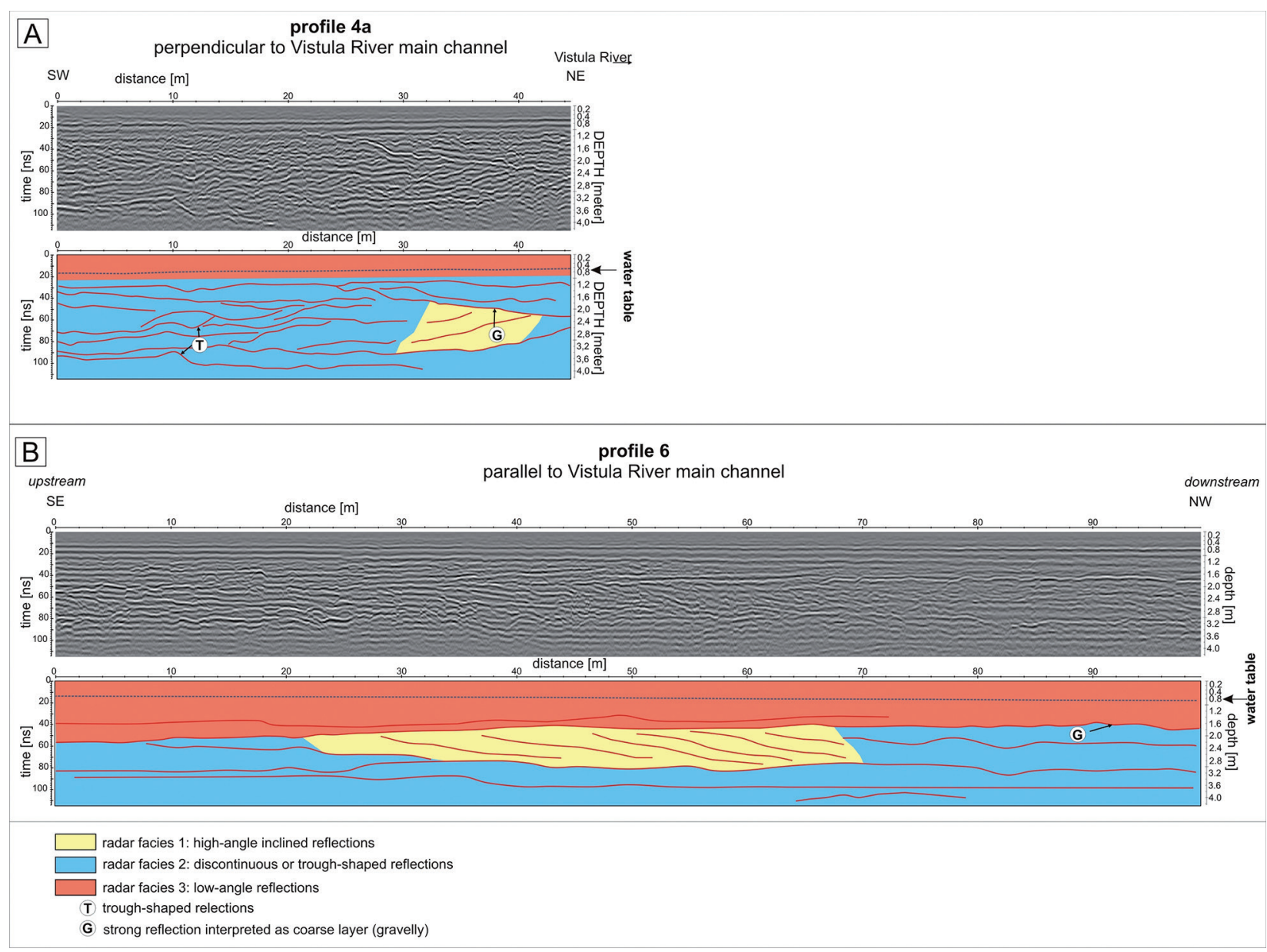

Fig. 5. GPR profiles obtained using 250-MHz antennas (site 2, 2011) with corresponding interpretations below. The GPR trace shows examples of three principal radar facies that are characteristic of the sandy braided-river deposits of the Vistula River.

A: Profile 4a running perpendicular to the main channel of the Vistula River; B: Profile 6 running parallel to the main channel of the Vistula River.

\subsection{Radar facies 2: discontinuous undulating or trough-shaped reflections}

Facies 2 is characterised by subparallel to oblique reflections. Sometimes these reflections look chaotic. The reflections are undulating to trough-shaped and discontinuous. They are interpreted as cross-strata formed by migrating dunes (cf. Ashworth et al., 2011).

\subsection{Radar facies 3: low-angle reflections}

Facies 3 is characterised by subparallel reflections with an almost planar shape. They consists of reflections with a dip angle of less than $6^{\circ}$ and they can be arranged in sets that dip downstream, upstream or laterally to the main channel. They are interpreted as strata accumulated by the migration of low-amplitude sand waves or unit bars.

\subsection{Overview of the GPR results}

Summarizing, the GPR method gives the best results in sediments of varied texture and structure (cf. Olszak \& Karczewski, 2008; Jol, 2009). The most important parameter controlling how clear the boundaries/reflections are, is the presence of water in the sediment. In the 2011 investigation, capillary water was present above the shallow groundwater table, i.e. the first $0.5 \mathrm{~m}$ from the surface downwards. 
Below that level, the sediments were in the saturation zone, so all pores were fully saturated with water. Thus, below the water table reflections will be affected only by structural and lithological factors. Water significantly increases the electrical conductivity, which adversely affects the propagation of a radar signal, causing its attenuation. Moreover, admixtures of clay and the content of iron compounds are important as well (Lamparski, 2004). Laboratory studies carried out by Van Dam (2001) have shown that iron hydroxides do not directly change the dielectric properties of a sediment. However, oxides and hydroxides have a much better water retention capacity than quartz grains which, in turn, affects the amplitude of the GPR signal (Van Dam, 2001).

\section{Conclusions}

This first combined sedimentological/geophysical study of the deposits of a sand-bed braided river in Poland yielded the following main conclusions on the basis of the combination of GPR studies and outcrop analyses.

Four major lithofacies groups were recognised in two outcrops of the Vistula River (Fig. 3): (1) stratified sands $(S h / S l, S p, S r)$ deposited from bedload transport, (2) massive fines $(F m)$ and organic deposits $(C)$ deposited under quiet conditions after flood events, (3) massive sands $(\mathrm{Sm})$ resulting from the disturbance of subsurface layers and (4) massive gravelly sands $(S G m)$ deposited from highly concentrated bedload transport. The lithofacies occur in a characteristic order (i.e., from base to top: $S$, $\mathrm{Sp}, \mathrm{Sh} / \mathrm{Sl} \rightarrow \mathrm{Fm}, \mathrm{C}, \mathrm{Sm}$; see Fig. 3) which indicates that the Vistula River environment is typically a bedload sand-bed braided river.

Grain-size analyses showed that mostly medium sands are present. Radar facies were consequently distinguished on the basis of differences in structural and textural properties of the sediments.

The GPR data of the 34 transects that were studied suggest the presence of three geophysically different units (as also distinguished by Sambrook Smith et al., 2006, and Ashworth et al., 2011): high-angle inclined reflections (radar facies 1), discontinuous undulating or trough-shaped reflections (radar facies 2), and low-angle reflections (radar facies 3). In all GPR profiles, discontinuous undulating or troughshaped reflections distinctly dominate (radar facies 2). Such undulating or trough-shaped reflection patterns are most typical of the sub-recent depositional style of the Vistula River.

All lithofacies distinguished in the outcrops were also recognized in the GPR profiles: the finest and the coarsest fractions ( $F m, C ; S G m)$ were visible as strong reflections (Figs 4 and 5); stratified sands $(S h / S l, S p, S r)$ are visible as radar facies 1 and radar facies 2; and radar facies 3 may be interpreted as massive sands $(\mathrm{Sm})$;

The presence of characteristic radar facies (reflection patterns) in the GPR profiles, the differentiation of lithofacies in braid bars, and the variability of the radar-facies distribution due to a spatially changing lithology of the Vistula River are quite well comparable with other modern sandy braided rivers (Vandenberghe \& Van Overmeeren, 1999; Van Dam \& Schlager, 2000; Skelly et al., 2003; Woodward et al., 2003; Neal, 2004; Sambrook Smith et al., 2006; Ashworth et al., 2011).

The present study was the first aimed at verifying the usefulness of ground-penetrating radar for the investigation of sandy braided-river deposits in the middle course of the Vistula River valley. The GPR research results show that this non-invasive method is very useful, indeed, for the interpretation of the alluvial architecture of Vistula River deposits. It is therefore concluded that the GPR method may be a good tool for recognising the alluvial architecture of older, Pleistocene terraces in the European lowlands. The present study suggests that an antenna with a frequency of $250 \mathrm{MHz}$ provides better (more clear) but less detailed images than those obtained with a $500-\mathrm{MHz}$ antenna. An antenna with a frequency of $250 \mathrm{MHz}$ is recommended for studies of sandy alluvial deposits.

\section{Acknowledgements}

The authors like to thank two anonymous reviewers for their constructive comments and many useful remarks, which greatly improved the final manuscript. The research was financed by the Fac- 
ulty of Geology, University of Warsaw, and by the Faculty of Civil Engineering, Warsaw University of Technology.

\section{References}

Ashworth, P.J., Sambrooh Smith, G.H., Best J.L., Bridge, J.S., Lane, S.N., Lunt I.A., Reesink, A.J.H., Simpson, C.J. \& Thomas, R.E., 2011. Evolution and sedimentology of a channel fill in the sandy braided South Saskatchewan River and its comparision to the deposits of an adjacent compound bar. Sedimentology 58, 18601883.

Babiński, Z., 1992. Współczesne procesy korytowe dolnej Wisły [The present-day fluvial processes of the lower Vistula River]. Geographical Notes 157, 171 pp. (in Polish with English summary).

Daniels, D.J., 2004. Ground-penetrating radar (2nd ed.). The Institute of Electrical Engineers, London, $726 \mathrm{pp}$.

Eyles, N., Eyles, C.H. \& Miall, A.D., 1983. Lithofacies types and vertical profile models; an alternative approach to the description and environmantal interpretation of glacial diamict and diamictite sequences. Sedimentology 30, 293-410.

Fal, B., Bogdanowicz, E., Czernuszenko, W., Dobrzyńska, I. \& Koczyńska, A., 1997. Przepływy charakterystyczne głównych rzek polskich w latach 1951-1990 [Characteristic flows in main Poland's rivers in the years 1951-1990]. Materiaty Badawcze IMGW, Seria Hydrologia i Oceanologia 21, 174pp. (in Polish)

Falkowski, T., 2006. Naturalne czynniki stabilizujące wybrane odcinki strefy korytowej Wisły środkowej [Factors of natural stability of the middle Vistula River channel zones]. Treatises and Monographs of Warsaw University of Life Sciences 312, 128 pp. (in Polish with English summary)

Folk, R.L. \& Ward, W.C., 1957. Brazos River bar: a study in the significance of grain size parameters. Journal of Sedimentary Petrology 27, 3-26.

Haczewski, G. \& Kukulak, J., 2004. Early Holocene landslide-dammed lake in Bieszczady Mountains (Polish eastern Carpathians) and its evolution. Studia Geomorphologica Carpatho-Balcanica 38, 83-96.

Hickin, A.S., Kerr, B., Barchyn, T.E. \& Paulen, R.C., 2009. Ground-penetrating radar and capacitively coupled resistivity to investigate fluvial architecture and grain-size distribution of a gravel floodplain in Northeast British Columbia, Canada. Journal of Sedimentary Research 79, 457-477.

Jol, H.M., 2009. Ground penetrating radar - theory and applications. Elsevier (London), 524 pp.

Karczewski, J., Ortyl, Ł. \& Pasterniak, M., 2011. Zarys metody georadarowej. Wydanie 2. [Outline of GPR method. 2nd edition] Wydawnictwa AGH (Kraków), 346 pp.

Lamparski, P., 2004. Formy i osady czwartorzędowe w świetle badań georadarowych [Quaternary forms and deposits in the light of ground penetrating radar investigations]. Prace Geograficzne 194, 1-115. (in Polish with English summary)
Leclerc, R.F. \& Hickin, E.J., 1997. The internal structure of scrolled floodplain deposits based on ground penetrating radar, North Thompson river, British Columbia. Geomorphology 21, 17-38.

Lunt, I.A., Bridge, J.S. \& Tye, R.S., 2004. A quantitative, three-dimensional model of gravelly braided rivers. Sedimentology 51, 377-414.

Miall, A.D., 1977. A review of the braided river depositional environment. Earth-Science Reviews 13, 1-62.

Miall, A.D., 1985. Architectural element analysis: a new method of facies analysis applied to fluvial deposits. Earth-Science Reviews 22, 261-308.

Mycielska-Dowigałło, E., 1995. Wybrane cechy teksturalne osadów i ich wartość interpretacyjna [Selected textural features of deposits and their interpretation value]. [In:] E. Mycielska-Dowgiałło \& J. Rutkowski (Eds): Metody badań osadów czwartorzędowych. Wybrane metody i interpretacja wyników [Research studies of the Quaternary sediments. Some methods and interpretation of the results]. Faculty of Geography and Regional Studies, University of Warsaw Press (Warszawa), 29-104. (in Polish with English summary)

Mycielska-Dowgiałło, E., 2007. Metody badań cech teksturalnych osadów klastycznych i wartość interpre tacyjna wyników [Research methods for textural features of clastic deposits and their significance for interpretation]. [In:] E. Mycielska-Dowgiałło \& J. Rutkowski (Eds): Badania cech teksturalnych osadów czwartorzędowych $i$ wybrane metody oznaczania ich wieku [Textural features studies of quaternary deposits and selected methods their age determination]. SWPR Press (Warszawa), 95-180. (in Polish with English summary)

Neal, A., 2004. Ground-penetrating radar and its use in sedimentology: principles, problems and progress. Earth-Science Reviews 66, 261-330.

Olszak, J. \& Karczewski, J., 2008. Przydatność profilowań georadarowych $\mathrm{w}$ interpretacji budowy tarasów rzecznych (dolina Kamienicy, polskie Karpaty zewnętrzne) [Usefulness of GPR measurements in interpretation of structures of river terraces (Kamienica River Valley, Polish Outer Carpathians)]. Przegląd Geologiczny 56, 330-334. (in Polish with English summary)

Racinowski, R., Szczypek, T. \& Wach, T., 2001. Prezentacja i interpretacja wyników badań uziarnienia osadów czwartorzedowych [Presentation and interpretation of the results on the granulation of quaternary sediments]. Silesian University (Katowice), 146 pp. (in Polish)

Rice, S.P., Church, M., Woolridge, C.L. \& Hickin, E.J., 2009. Morphology and evolution of bars of a wandering gravel-bed river; lower Fraser river, British Columbia, Canada. Sedimentology 56, 709-736.

Sambrook Smith, G.H., Ashworth, P.J., Best, J.L., Woodward, J. \& Simpson, C.J., 2006. The sedimentology and alluvial architecture of the sandy braided South Saskatchewan River, Canada. Sedimentology 53, 413-434.

Skelly, R.L., Bristow, Ch.S. \& Ethridge, F.G., 2003. Architecture of channel-belt deposits in an aggrading shallow sandbed braided river: the lower Niobrara river, northeast Nebraska. Sedimentary Geology 158, 249-270. 
Słowik, M., 2011. Reconstructing migration phases of meandering channels by means of ground-penetrating radar (GPR): the case of the Obra River, Poland. Journal of Soils and Sediments 11, 1262-1278.

Słowik M., 2012. Influence of measurement conditions on depth range and resolution of GPR images: the example of lowland valley alluvial fill (the Obra River, Poland). Journal of Applied Geophysics 85, 1-14.

Starkel, L., 2011. Historia doliny Wisły od ostatniego zlodowacenia do dziś [Evolution of the Vistula River valley since the last glaciation till present]. Monographies of Polish Academy of Science 2, 263 pp. (in Polish with English summary)

Van Dam, R. L., 2001. Causes of ground-penetrating radar reflections in sediment. Ph.D. thesis Vrije Universiteit Amsterdam, 110 pp.

Van Dam, R.L. \& Schlager, W., 2000. Identifying causes of ground-penetrating radar reflections using time-domain reflectometry and sedimentological analyses. Sedimentology 47, 435-450.

Vandenberghe J. \& Van Overmeeren, R.A., 1999. Ground penetrating radar images of selected fluvial deposits in the Netherlands. Sedimentary Geology 128, 245-270.

Woodward, J., Ashworth, P.J., Best, J.L., Sambrook Smith, G.H. \& Simpson, C.J., 2003. The use and application of GPR in sandy fluvial environments: methodological considerations. [In:] C.S.Bristow \& H.M. Jol (Eds): Ground penetrating radar in sediments. Geological Society, London, Special Publications 211, 127-142.
Zieliński, T., 1995. Kod litofacjalny i litogenetyczny konstrukcja i zastosowanie [Lithofacies and genetic codes: construction and application]. [In:] E. Mycielska-Dowgiałło \& J. Rutkowski (Eds): Metody badań osadów czwartorzędowych. Wybrane metody i interpretacja wyników [Research studies of the Quaternary sediments. Some methods and interpretation of the results]. University of Warsaw Press (Warszawa), 220-235. (in Polish with English summary)

Zieliński, T., 1998. Litofacjalna identyfikacja osadów rzecznych [Lithofacial identification of alluvial sediments]. [In:] E. Mycielska-Dowgiałło (Ed.): Struktury sedymentacyjne sedymentacyjne $i$ postsedymentacyjne postsedymentacyjne w osadach czwartorzędowych [Sedimentary and postsedimentary structures in Quaternary sediments and their value for interpretation]. Faculty of Geography and Regional Studies, University of Warsaw Press (Warszawa), 195-260. (in Polish)

Zieliński, T. E Pisarska-Jamroży, M., 2012. Jakie cechy litologiczne osadów warto kodować, a jakie nie? [Which features of deposits should be included in a code and which not?] Przeglad Geologiczny 60, 387397. (in Polish with English summary).

Manuscript received: 20 May 2013 Revision accepted: 13 January 2014 